\title{
MENGUKUHKAN PESANTREN SEBAGAI BASIS \\ PEMBELAJARAN KITAB KUNING: \\ PP. Salafiyah Al Falah Ploso Kediri Jawa Timur
}

\section{Reinforcing Islamic Boarding School as The Basis of Islamic Book With Arabic Script Learning \\ PP. Salafiyah Al-Falah Ploso Kediri East Java}

\author{
Farida Hanun
}

\author{
Puslitbang Pendidikan Agama dan Keagamaan \\ Badan Litbang dan Diklat Kementerian Agama \\ Email: farida_ridwan@yahoo.com
}

Naskah diterima tanggal 4 Desember 2012. Naskah direvisi tanggal 27 Desember 2012. Naskah disetujui tanggal 15 Januari 2013

\begin{abstract}
Abstrak
Penelitian ini bertujuan untuk mengetahui sistem pendidikan di pesantren $\mathrm{Al}$ Falah Ploso, dan faktorfaktor yang mempengaruhi kualitas pengajaran kitab kuning di pesantren Al Falah Ploso. Metode yang digunakan adalah metode kualitatif. Hasil penelitian menunjukkan: Pondok Pesantren Al Falah telah melakukan inovasi sistem pendidikan dari sistem tradisional (non klasikal) berupa pengajian sorogan dan wetonan, kemudian ditambahkan dengan sistem pendidikan klasikal (Madrasah Ibtidaiyah, Tsanawiyah dan Aliyah, serta Riyadlotut Tolabah). Kedua, faktor penunjang penguasaan kitab kuning: komitmen kyai yang tinggi, kompetensi ustadz, input santri yang berkualitas, efektifitas kurikulum yang digunakan, tingginya kitab-kitab kuning yang digunakan, sarana dan dana yang menunjang.
\end{abstract}

Kata kunci: pembelajaran, kitab kuning, pesantren

\begin{abstract}
This study aims to identify the education system in Al Falah Ploso Islamic boarding school, and the factors affecting the quality of Islamic book with Arabic script (Kitab Kuning) teaching. The method used was the qualitative method. The results showed that Al Falah Ploso Islamic boarding school has carried out innovation in its education system which was from traditional system (non-classical) in the form of sorogan and wetonan, then added with a classical education system (in Islamic elementary schools, Islamic Junior High Schools, Islamic Senior high Schools, and Islamic Kindergarten). Second, the supporting factors of Islamic book with Arabic script (Kitab Kuning) mastery were the great commitment of Islamic experts (kyai), the competence of Islamic teacher, the qualified students' input, the effectiveness of the used curriculum, the top level of used Islamic book with Arabic script (Kitab Kuning), as well the supporting funding and facilities.
\end{abstract}

Keywords: learning, islamic book with arabic script (kitab kuning), islamic boarding school

\section{PENDAHULUAN}

$\mathrm{P}$ esantren sebagai lembaga pendidikan Tafaqquh Fiddin, memiliki peran lebih luas karena memilki beberapa potensi diantaranya: a) potensi intelektual (memiliki tradisi keilmuan dalam penguasaan ilmu agama; ahli Tafsir, Hadits,
Fiqh, dll, b) peran sosial (kyai sebagai pemipin spiritual keagamaan membantu menyelesaikan masalah-masalah keseharian di masyarakat, dengan kondisi ini menuntut pesantren untuk menjaga kesinambungan kepemimpinan spiritual dan moral agama dengan mempersiapkan calon-calon ulama dan da'i/muballigh c) potensi kultural, pesantren 
memiliki elemen-elemen kyai, santri, masjid, pondok dan kitab kuning. Melalui tradisi yang dikembangkan pesantren mampu membangun lingkungan social cultural yang memungkinkan komunitas pesantren membiasakan diri hidup dalam tradisi santri yang sarat dengan nilai-nilai moral dan kesalehan individual.

Dalam dasa warsa terakhir, dunia pesantren (sebagai lembaga pendidikan Tafaqquh Fiddin) secara perlahan melakukan proses adaptasi, inovasi sampai dengan kepada mengadopsi sistem di luar pesantren. Sekarang ini pesantren mulai menyelenggarakan pendidikan madrasah dan sekolah umum dari jenjang pra sekolah, dasar menengah sampai ke perguruan tinggi.

Perkembangan pesantren tersebut memunculkan berbagai variasi pesantren. Dilihat dari segi keterbukaanya terhadap perubahan-perubahan yang terjadi, menurut Dhofier (1994:41-42) terdapat dua katagori pesantren yaitu: pesantren salafiyah, para santri hanya mengikuti pengajian kitab-kitab dan pesantren khalafiyah yang para santrinya selain mempelajari kitab juga memasukkan pelajaranpelajaran umum.

Di Indonesia banyak sekali berdiri pondok pesantren baik salafiyah maupun kholafiyah. Sistem pendidikan pesantren yang masih salafi murni tidak banyak lagi. Pesantren besar biasanya sudah berkembang menjadi pesantren khalafi (yang memasukkan mata pelajaran umum sesuai dengan sistem pendidikan nasional). Sementara itu pesantren kecil yang tetap bertahan pada bentuk salafi biasanya kurang mampu berkembang secara kondusif (Qomar, 2007:10).

Namun demikian ada sejumlah pesantren salaf yang masih eksis sampai sekarang, misalnya pesantren Al Falah Ploso Kediri. Pesantren Al Falah yang berdiri tahun 1924 merupakan pesantren salafiyah yang yang tetap mempertahankan sistem pendidikan salafiyahnya atau memegang teguh prinsip salafnya dan ajaran Ahlus-sunnah wal Jamaah yang diamanatkan oleh para pendahulunya KH. Djazuli, dengan tidak mengabaikan modernitas dan era globalisasi yang tengah berkembang di lingkungan masyarakatnya.

Sistem pendidikan yang dianutnya lebih menampakkan wajah pendidikan periode masa lalu dengan segala keunikannya dan berbeda dengan sistem pendidikan sekarang pada umumnya. Setiap santri yang keluar masuk pondok selalu menggunakan sarung, kemeja dan kopiah (songkok), bahkan ada pula yang tidak menggunakan alas kaki atau sandal. Dengan keunikannya tersebut justru memperoleh tempat tersendiri dikalangan masyarakat dan menjadi kunci utama pesantren tersebut dalam mempertahankan keberadaannya.

Seiring dengan berjalannya waktu, pesantren Al Falah dalam sistem pembelajaran kitab kuningnya telah melakukan inovasi mulai kondisi awal dengan sistem tradisional (non klasikal) berupa sorogan dan wetonan, kemudian sekarang ditambahkan sistem pendidikan klasikal yaitu Madrasah Diniyah.

PP Al Falah telah melakukan inovasi pembelajaran kebentuk klasikal, tapi data dan informasi mengenai kualitas santri yang belajar kitab kuning saat ini belum diketahui. Dengan alasan itu maka penelitian ini perlu dilakukan.

Rumusan masalah dalam penelitian ini adalah bagaimana sistem pendidikan di pesantren Al Falah Ploso? Dan faktor-faktor apa saja yang mempengaruhi kualitas pengajaran kitab kuning di pesantren Al Falah Ploso?

\section{Tinjauan Pustaka}

\section{Peran Pondok Pesantren}

Pesantren yang merupakan lembaga pendidikan tradisional Islam, ikut terlibat dalam upaya mencerdaskan kehidupan bangsa, tidak hanya dari segi moril, namun telah pula ikut serta memberikan sumbangsih yang cukup signifikan dalam penyelenggaraan pendidikan. Hal ini sesuai dengan perannya sebagai: a) transmisi ilmu-ilmu dan pengetahuan Islam (transmision of Islamic knowledge), b) pemeliharaan tradisi Islam (maintenance of Islmic tradition), dan c) reproduksi (calon-calon) ulama (reproduction of ulama) (Burhanuddin, 2006:13). Sebagai pusat pengajaran ilmu-ilmu agama Islam (tafaqquh fiddin) telah banyak melahirkan ulama, tokoh masyarakat, muballigh, guru agama yang sangat dibutuhkan masyarakat.

\section{Unsur-unsur Sistem Pendidikan Pesantren}

Dhofier mengemukakan lima unsur pondok pesantren yang melekat atas dirinya meliputi kiai, santri, pondok, masjid dan pengajaran kitab-kitab klasik (Dhofier: 1994:25). Pertama, Kyai. Suatu lembaga pendidikan Islam disebut pesantren apabila memiliki tokoh sentraI yang disebut kyai, jadi kyai di dalam dunia pesantren sebagai penggerak dan mengembangkan pesanten sesuai dengan pola yang dikehendaki. Kedua, Santri. Ada dua tipologi santri yaitu santri mukim (santri yang menetap tinggal 
bersama kyai dan secara aktif menuntut ilmu dari seorang kyai) dan santri non mukim/kalong (seorang murid yang berasal dari desa sekitar pesantren yang pola belajarnya tidak menetap di dalam pondok pesantren). Ketiga, Pondok. Istilah pondok diartikan juga dengan asrama sebagai tempat tinggal santri yang berdatangan dari luar daerah. Keempat, Masjid. Selain menjadi tempat ibadah, masjid biasanya menjadi cikal bakal pengembangan pondok pesantren. Seorang kyai yang ingin mengembangkan pondok pesantren biasanya pertama-tama mendirikan masjid sebagai tempat aktifitas peribadatan dan pendidikan.

Kelima, Pengajaran Kitab Kuning. Kitab kuning sering disebut al-kutub al-qadimah, karena kitab-kitab tersebut dikarang lebih dari seratus tahun yang lalu. Ada juga yang menyebutkannya sebagai al-kutub al-shafra' atau "kitab kuning" karena biasanya kitab- kitab itu dicetak di atas kertas berwarna kuning, sesuai kertas yang tersedia waktu itu. Ciri lain dari literatur yang dipergunakan di pesantren itu ialah beraksara Arab Gundul (huruf Arab tanpa harakat atau syakal) (Abdul Faffat, 2005: 22).

Kitab-kitab kuning yang biasa dikaji di pesantren, penulisannya memilki latarbelakang yang beragam. Bila dilihat dari gaya penyajian atau pemaparannya, kitab kuning dapat dikelompokkan menjadi: Kitab Nasr, Kitab Nadzam, dan kitab Mukhtashar (Abdul Fattah, 2005: 2529). Pertama, Kitab-kitab natsr (esai) ialah kitab yang dalam menyajikan materinya menggunakan essai (natsr). Kedua, Kitab-kitab nadzam. Cara penyajian materi dengan menggunakan nadzam atau syi'ir (sair), Contoh kitab ini misalnya Hidayat al-Shibyan. Ketiga, Kitab Mukhtashar, menyajikan materinya dengan cara meringkas materi suatu kitab yang panjang lebar untuk dijadikan karangan singkat tetapi padat (kitab Alfiyah ibn Malik yang merupakan ringkasan dari kitab al-Kafiyah.

\section{Diagram 1 Sistem Pembelajaran Kitab Kuning di Pesantren Al Falah Ploso}

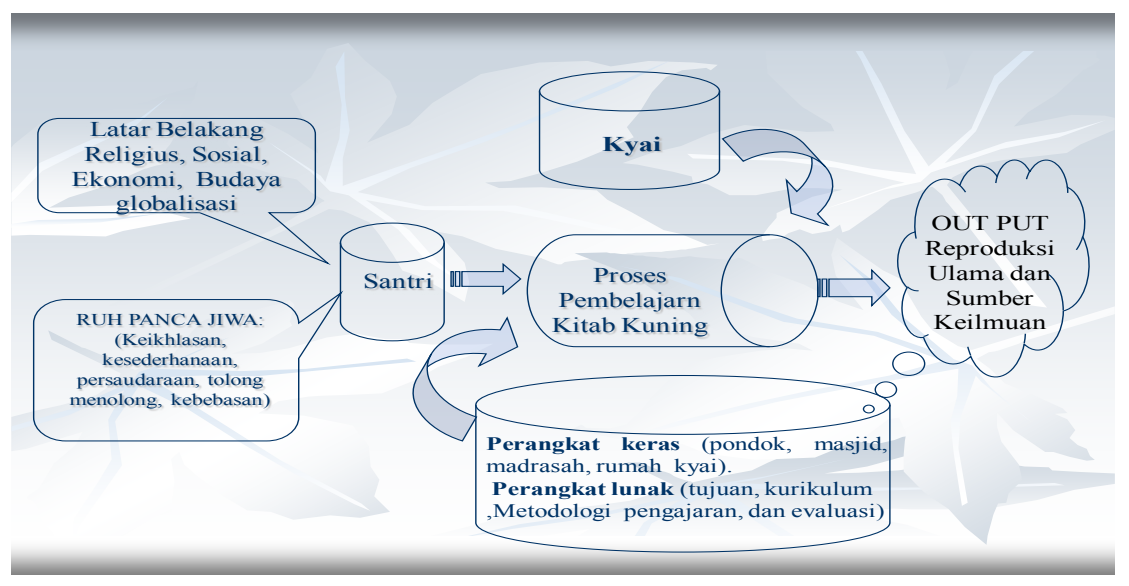

\section{Tingkatan Pengajaran Kitab Kuning}

Di beberapa pesatren salafiyah yang masih eksis hingga sekarang, terdapat tingkatan-tingkatan pengajaran kitab kuning. Dalam bidang Nahwu, kitab kuning pemula adalah Al-Awamil Al-Miah karya Abd Al-Qahir Ibn Abdirrahman Al-Jurjani (w. 471 $\mathrm{H})$ dan Al-Muqaddimah Al-Ajrumiyyah karya $\mathrm{Abu}$ Abdillah Ibn Dawud Al-Shanhaji bin Ajrum (w. 723 $\mathrm{H})$, tingkat menengah menggunakan $\mathrm{Al}$-Durar $\mathrm{Al}$ Bahiyyah yang dikenal dengan 'Imrithi karangan Syarf Ibn Yahya Al-Anshari Al-Imrithi dan lebih tinggi lagi menggunakan kitab kuning Al-Mutammimah karya Samsuddin Muhammad bin Muhammad Al-Ru'yani Al-Khatabi dan kitab Alfiyyah Ibn Malik beserta kitab kuning syarkh yang dikenal dengan Ibn Aqil anggitan Abdullah bin Abdirrahman AlAqil.

Bruinessen membuat tingkat kesulitan kitab kuning dengan menggunakan istilah nama-nama tingkatan madarasah, yaitu ibtidaiyah, tsanawiyah, aliyah dan khawash (Bruinessen, 1995: 115-151). Fath al Qorib, Fath al Mu'in, Fath al Wahhab merupakan kitab tingkat menengah dalam pesantren. Kitab Fathil Qorib merupakan kitab fiqh yang ditulis oleh Ibn Qosim Al Ghuzzi (w. 918 H), kitab Fathil Mu'in ditulis oleh Zaenudin Al Malibari (w.975 H) dan kitab Fathil Wahhab ditulis oleh Zakariya al Anshari (w. 926 H/ 1520 M). Di kalangan Pesantren 
di Indonesia ketiga kitab tersebut menjadi kitab rujukan utama dalam forum-forum musyawarah untuk istimbat hukum (pengambilan dasar hukum).

Mabadi Fiqh (juz 1-4), Sullam al Taufiq, karya Abdullah Bin Hasan Bảawi (w. 1272 H/ 1855 M) dan Safinah an Najah karya Salim bin Abdullah bin Husain bin Samir (abad 19) merupakan kitab fiqh dasar yang banyak diajarkan dikalangan pesantren dan madrasah diniyah pada level ibtidaiyah, maksimal pada level Tsanawiyah saja. Al Iqna', merupakan kitab fiqih yang tergolong sedang, yang ditulis oleh Syamsudin Muhammad Bin Ahmad Al Khatib Asy Syarbaini (w. 977 H/ 1570 M). Di pesantren di Indonesia Al Iqna' ini diajarkan di level Tsanawiyah.

Tafsir Jalalain. Kitab ini ditulis oleh Imam Mahalli dan Imam Jalaludin As Suyuthi (w.911H) pada abad ke sepuluh. Sebagai kitab yang sangat popular dikalangan pesantren di Indonesia, tafsir Jalalain ini kebanyakan diajarkan pada level yang tinggi yaitu level Aliyah. Selanjutnya Kitab Jawahir Bukhori, Tajridus Shorikh, Majalisus Saniah, Abi Jamroh, Riyadus Sholihin, merupakan kitab hadist yang bukan kitab utama yang diajarkan atau masuk dalam kurikulum, akan tetapi kitab yang diajarkan khusus kepada para santri yang dipandang telah mampu setidaknya pada level aliyah. Sedangkan Kitab Ihya' Ulumiddin, Bidayatul Hidayah dan Minhajul 'abidin merupakan kitab karya Abu Hamid al Ghozali (450-550 H/1058-1111 M). Ketiga kitab tersebut berisi ajaran moral yang sangat tinggi bagi kalangan pesantren dan diajarkan pada level yang tinggi.

\section{Kajian Terdahulu}

Martin Van Bruinessen (1999: 131-132) menemukan lima kajian kitab-kitab yang tidak ditemukan kajian Berg, yaitu hadist, tarikh, mantik, ushul fiqh dan mantiq. Penelitian lain dilakukan oleh Mastuhu (1993: 170-173), terdapat sekitar 7 bidang kajian agama Islam di jawa yaitu: (tauhid, tafsir, hadis, fikih, usul fikih, tasawuf, nahwu/ saraf/ balagah, mantik dan ahlak) dan menggunakan 112 macam kitab.

Menurut Fatta, Taufik dan Bisrih, (2005:3547) mengelompokkan 11 bidang disiplin ilmu: Bidang Aqidah / Ilmu Tauhid, Bidang Tajwid (Baca al-Qur'an), Bidang Akhlaq/Tasawuf, Bidang Bahasa Arab (Nahwu - Sharaf), Bidang Fiqih, Ushul Fiqih, Bidang Ulumul Qur'an, Bidang Hadits, Bidang Ulumul Hadits, dan Bidang Tarikh (Sejarah Islam).

\section{METODOLOGI PENELITIAN}

Penelitian ini merupakan studi kasus dengan metode yang digunakan melalui pendekatan kualitatif. Sasaran penelitian adalah pesantren salafiyah Al Falah Ploso Kab. Kediri yang mengajarkan kitab-kitab turast/kitab kuning yang secara tradisi pengajaran Kitab kuningnya kuat dan sudah memiliki jaringan alumni yang banyak tersebar di masyarakat.

Sumber data diperoleh melalui informan yaitu pimpinan pondok (kyai), ustadz, santri, masyarakat. Teknik pengumpulan data dilakukan melalui angket, wawancara mendalam, dokumentasi, dan observasi.

\section{PEMBAHASAN \\ Profil Pesantren Al Falah Ploso \\ Visi dan Misi}

Visipondokpesantren AlFalah adalah lembaga pendidikan dan pengajaran agama Islam yang sejak berdirinya tetap mempertahankan konsep salafiyah dengan menganut thoriqoh ta'lim wattállum, senantiasa menjadi rujukan pengembangan keislaman dan dakwah multikultural. Sedangkan misinya meliputi: mengembangkan pesantren secara keilmuan dan kelembagaan, melakukan pencerahan kepada masyarakat melalui kegiatan tảllum, tarbiyah \& tadib dan meningkatkan kompetensi lulusan pondok pesantren melalui pembekalan moral, skill dan penguatan di bidang ilmiyah amaliyah, amaliyah ilmiyah serta pengembangan wawasan.

\section{Kepemimpinan}

Berkaitan dengan pimpinan pesantren $\mathrm{Al}-$ Falah Ploso, periode pertama berdirinya dipimpin oleh KH. A. Djazuli Usman, tapi kemudian ketika beliau meningal tahun1976 maka kepemimpinan PP Al Falah Ploso periode ke dua di pimpin secara kolektif oleh anak-anaknya yaitu: 1 . KH. Zainuddin Djazuli, 2. KH. Nurul Huda, 3. Alm. KH Chamin, 4. KH. Fuad Mun'im (Gus Fu'), 5. Alm. KH. Munif, 6. Bu Nyai Hj. Badriyah (Bu Bad). Kalau dulu pada periode pertama seluruh kebijakan pesantren berada di tangan KH Alm Djazuli, maka pada periode ke dua seluruh kebijkan pesantren diputuskan secara sistem kolektif. Kepemimpinan didelegasikan dalam bentuk dewan dan sub bidang yang melibatkan selain anak dan cucu KH Djazuli juga merangkul para alumni. Hal ini berbeda dengan kebanyak tipe pesantren salafiyah yang biasanya berbentuk 
kepemimpinan tunggal ada di tangan kyai (Aqil Siraj, 2007).

\section{Jaringan Intelektual Kyai}

Mas'ud demikian nama kecil dari KH. A. Djazuli Utsman lahir pada tanggal 16 Mei 1900 di Ploso (Mu’allimin, dkk, 2007: 10). Mas'ud ketika bermur 6 tahun bersekolah di sekolah Arab (sekolah cap jago). Umur 9 tahun melanjutkan ke Inlandsche Vervolg School milik Belanda ditamatkan selama 2 tahun. Selanjutnya masuk ke tingkat SLTA di Hollandsch-Inlandsche School (HIS) di Kediri. Setamat dari HIS, Mas'ud melanjutkan ke jenjang perguruan tinggi ke STOVIA (Fakultas kedoketran UI Batavia Jakarta). Namun atas saran dari Kyai Ma'ruf Kedunglo (murid dari Kyai Kholil Bangkalan) sebaiknya Mas'ud di masukkan ke pondok pesantren.

Pada usia 16 tahun Mas'ud pergi ke PP. Gondanglegi Nganjuk pimpinan KH. Ahmad Sholeh untuk belajar bidang Ulumul Qur'an dan ilmu Nahwu. Selanjutnya ke PP. Sono-Sidoarjo belajar ilmu Shorof dan sempat mondok di PP. Sekar putih. Mas'ud belajar kembali ke PP. Mojosari pimpinan Kyai Zainuddin. Dan kemudian pindah ke PP. Langitan mengikuti mertuanya membantu mengembangkan pondok. Ketika ke tanah suci Mekkah sempat berguru dengan Syekh Al-'alamah Al-Aidrus di Jabal Hindi Mekkah.

Tahun 1923 berangkat ke PP. Tebuireng Jombang pimpinan Kyai Hasyim Asy'ari untuk mempelajari Ilmu Hadits. Tahun 1924 mendirikan PP. Al Falah Ploso. Dan tahun 1927 mendirikan madrasah Abang (pembukaannya dihadiri $\mathrm{KH}$. Hasyim Asy'ari). Dan tahun 1928 membangun pondok/asrama Darusalam dan pondok Cahaya, tempat penginapan santri. Pada tanggal 15 Agustus tahun 1930 H. Djazuli menikah dengan Roro Marsinah (putri dari Kyai Imam Mahyon). Bersama dengan istrinya (Nyai Rodliyah nama panggilan Roro Marsinah) yang pandai berwirausaha dan Kyai Djazuli yang sibuk dengan kegiatan mengajarnya, berhasil membesarkan 6 anaknya (1. KH. Zainuddin Djazuli, 2. KH. Nurul Huda, 3. Alm. KH Chamin, 4. KH. Fuad Mun'im (Gus Fu'), 5. Alm. KH. Munif, dan, 6. Bu Nyai Hj. Badriyah (Bu Bad).

Sejak tahun 1950 pesantren Al Falah Ploso menjadi sebuah lembaga yang berwibawa dan bergengsi sampai sekarang dan merupakan duplikat pondok Tebuireng di masa KH. Hasyim Asy’ari tahun 1923 (Mu’allimin, dkk, 2007:117), walau sistem pendidikan Tebuireng saat sekarang sudah mengalami perubahan yaitu tidak pesantren salafiyah murni lagi melainkan berubah ke pesantren modern yang selain memberikan pelajara kitab kuning juga memberikan pelajaran umum sejak pesantren beralih dari Kyai Hasyim ke Kyai Moch. Ilyas dan Kyai Abd Wahid.

\section{Sistem Pengajaran Kitab Kuning}

PP Al Falah adalah sebuah lembaga pendidikan dan pengajaran Islam Ala Thoriqoh Salafiyah dengan sistem pendidikan klasikal dan non klasikal, dengan menggunakan kurikulum yang merujuk ke PP. Tebuireng Jombang dimasa kepemimpinan $\mathrm{KH}$. Hasyim Asy'ari baik yang menyangkut penjenjangan maupun kitab-kitab yang digunakan.

\section{Sistem Klasikal}

Sistem klasikal ini merupakan jenjang pendidikan yang wajib diikuti santri dalam menuntut ilmu di PP Al Falah terdiri 3 (tiga) jenjang Pendidikan yang dikelola melalui Madrasah Islamiyah Salafiyah Riyadlotul 'Uqul (MISRIU) adalah; Madrasah Ibtidaiyah, Madrasah Tsanawiyah, dan Madrasah Aliyah. Kegiatan sekolah tingkat tsanawiyah dan aliyah di mulai pukul 07.30 wib sampai pukul $11.00 \mathrm{wib}$, sedangkan untuk tingkat ibtidaiyah kegiatan sekolah dimulai pukul 07.30 wib sampai pukul 10.30 wib, dengan memakai bahasa pengantar yaitu bahasa Indonesia. Sebelum kegiatan sekolah, terlebih dahulu dilaksanakan kegiatan musyawarah. Bagi siswa tingkat tsanawiyah dan aliyah diskusinya (musyawarah ) dimulai pukul 20.00 wib s.d pukul 22.30 wib. Sedangkan untuk tingkat ibtidaiyah dimulai pukul 20.00 wib sampai pukul 22.00 wib.

Berkaitan penggunaan kitab-kitab kuning di tingkat ibtidaiyah meliputi: Akhlaq (Mathlab, Tambihul Mutáallim, Washoya), Tauhid (Aqidatul 'Awam, Khoridatul Bahiyah, Bad ul Amali), Tajwid (Hidayatus Syi byan, Tuhfatul Athfal, Hidayatul Mustafid), Fiqh (Mabadi Fiqh I,II, III, Tanwirul Hija), Tarikh (Tarikh Nabi, Nurul Yaqin I, II), Al Qur an, Nahwu (Sabrowi).

Pada Tingkat Tsanawiyah, kitab-Kitab Kuning di tingkat tsanawiyah meliputi: Nahwu (Jurumiyah, Al Imrithi), Shorof (Qowa'idul I'lal \& Qowa'idusshorfi, Maqsud, Tauhid (Tijanuddurorie Jawahirul Kalamiyah, Jauhar tauhid), Fiqh (Riyadlul badi ah, Sulamut taufiq). Sedangkan untuk tingkat 
Aliyah, kitab-kitab kuning di tingkat ini meliputi: Nahwu (Alfyah), Mantiq [Sulam munauroq], Faroidl (Rohabiyah, Iddatul] faridl), Fiqh (Fathil qorib, Fathul qorib II]), Usul fiqh (Lathoif isarot), Falak (Durus falakiyah, Balaghoh (Jw. Maknun), Hisab (Rislh. Nayyiroin), Qowaid fiqh (Faroidl bahiyah), Mustholah (Baiquniyah), Arudl (Muhtashor safi).

Bagi siswa yang mendaftarkan mulai bulan shofar akan di masukkan dalam komunitas tersendiri yaitu sekolah persiapan (I'dadiyah). Kitab-Kitab Kuning di tingkat Sekolah Persiapan (SP) meliputi: Tajwid (Tuhfatul athfal, hidayatul mustafid), Nahwu (Jurumiyah), Fiqh (Mabadi fiqh 1-4), Safinatunnaja), Tauhid (Aqidah awam, Tijan durori), Tahsinul khot, Sorof (Q .sorfi). I'lal (Q .i'lal).

Setelah selesai menamatkan jenjang MISRIU ini, segenap siswa diwajibkan masuk dan mengikuti jenjang di atasnya yaitu Riyadlotut Tolabah. Jenjang ini terdiri tiga fraksi: Fraksi I, lamanya 1 tahun, kajian pokok kitab Fathil Qorib. Fraksi II lamanya 1 tahun, kajian pokok kitab Fathil Mu'in. Fraksi III lamanya 3 tahun, kajian pokok kitab Fathil Wahhab.

\section{Sistem Non klasikal}

Sistem pembelajaran ini meliputi: Pengajian sorogan, bandongan dan wetonan. Pengajian di PP.Al Falah yang wajib diikuti semua santri dilaksanakan setelah sholat Ashar dan setelah sholat Maghrib. Kitab-kitab yang dikaji setelah sholat Ashar adalah Kitab Fathil Qorib, Ta'limul Mutáallim, Bidayatul Hidayah Dan Shohih Bukhori.

Di samping sistem pendidikan klasikal dan non klasikal, ada juga pendidikan extra (penunjang) yang harus diikuti semua santri antara lain: 1) latihan ketrampilan berorganisasi, 2) baca Tahlil dan Surat Yasin, Muhafadhoh (Hafalan), Dibaiyyah, kegiatan setiap menjelang maghrib dan Mujahadah, 3) praktek mengajar, 4) seni baca Al Qur'an dan seni kaligrafi. Adapula kegiatan Bahtsul Masai. Bahtsul Masail Intern: membahas masalahwaqi'iyah yang belum bisa dipecahkan, baik pada tingkat Fathil Qorib Fathil, Fathil Mu'in maupun Fahil Wahhab. Sedangkan Bahtsul Masail extern: setiap tahun sebagai pra Tahtiman Fathil Qorib dan Fathil Mu'in yang diikuti pesantren se Jawa Timur, dan yang diprakarsai FMPP (Forum Musyawarah Pondok Pesantren) dibawah naungan RMI (Rabithoh Mảahidil Islamiyah) Jawa Timur.

\section{Faktor penunjang dan kendala pembelajaran Kitab Kuning}

Untuk menghasilkan alumni santri yang menguasai kitab kuning di PP Al Falah, banyak faktor penunjang yang mempengaruhi hasil pembelajaran kitab kuning diantaranya:

\section{Komitmen kyai}

Para Kyai PP. Al Falah Ploso, selalu berkomitmen untuk a) Kyai Djazuli Istiqomah mengajarkan kitab kuning kepada para santri dengan terjun langsung mengajarkan kitab (Mu'allimin, 2007:148). Setelah beliau wafat, tradisi ini diteruskan oleh putra-putri dan cucu-cucunya yang ikut mengajar. Iklim yang sudah tercipta seperti ini akan sangat berpengaruh terhadap kualitas penguasaan kitab kuning, b) Para kyai selalu mengajar tepat waktu, bila berhalangan hadir dicari guru pengganti, sehingga kegiatan belajar mengajar tetap berjalan. Keteladanan ini tentunya berdampak semakin meningkatnya kedisiplinan para santri dan terjadi akselerasi kemampuan para santri di dalam menguasai materi pembelajaran kitab kuning.

\section{Kompetensi Ustadz}

Di PP. Al Falah Ploso ini, memiliki staf pengajar di Ibtidaiyah sejumlah 11 orang, tsanawiyah sejumlah 21 orang, dan Aliyah sejumlah 19 orang serta musyawaroh Riadlotuttholabah sejumlah 6 orang (Dokumen profil ustadz di PP. Al Falah Ploso, 2012). Sementara itu, yang diangkat menjadi ustadz harus lulusan dari PP. Al Falah Ploso dimana mereka semua adalah hasil didirikan dari KH. Ahmad Djazuli beserta putra-putranya. Para ustad harus memiliki keilmuan tinggi yang sesuai dengan paham Ahlussunnah wal Jamaiah, adab, kedisiplinan, ahli tirakat dan sudah menamatkan jenjang musyawirin (Riyadlotut Tholabah) yang merupakan jenjang tertinggi di PP. Al Falah. Untuk sampai menyelesaikan jenjang musyawirin membutuhkan waktu belajar 12 tahun (Ibtida=3 th, $M T s=2$ th, MA=2 th dan musyawirin 5 tahun) (wawancara dengan Gus Thoif, 26 September 2012)

\section{Peran Santri}

Penerimaan siswa/santri baru dilakukan oleh panitia khusus, dengan sistem melalui tes seleksi (lisan, tulis dan membaca Alquran). Penentuan tingkatan kelas sesuai dengan kemampuannya ketika mengikuti tes masuk dan siswa yang mendaftar pasti diterima sesuai dengan kemampuannya. Jumlah 
santri secara keseluruhan pada tingkat ibtidaiyah sejumlah 303 orang, tsanawiyah sejumlah 665 orang, dan aliyah sejumlah 574 orang serta musyawaroh Riadlotuttholabah sejumlah 225 orang (Dokumen perkembangan santri 2012).

Dalam rangka memperdalam kitab kuning maka kebijakan pesantren adalah mewajibkan santrinya mukim di pesantren. Pada pengajian klasikal (diniyah) ada 1000 santri mukim dan hanya 150 santri yang tidak mukim. Sedangkan santri yang belajar ngaji tidak klasikal (pengajian) sekitar 200 orang yang mukim dan selebihnya 50 santri yang tidak mukim. Adanya beberapa santri yang tidak mukim, kebanyakan berasal dari lingkungan masyarakat sekitar pesantren yang tinggalnya sangat dekat dengan pondok sehingga tidak perlu menginap (Dokumen perkembangan santri 2012).

\section{Kurikulum yang digunakan}

Rangkaian program kegiatan pendidikan yang wajib diikuti santri pada tingkat tsanawiyah dan aliyah di mulai pukul 07.30 wib sampai pukul 11.00 wib, sedangkan untuk tingkat ibtidaiyah kegiatan sekolah dimulai pukul 07.30 wib sampai pukul 10.30 wib. Bagi siswa tingkat tsanawiyah dan aliyah diskusinya (musyawarah) dimulai pukul 20.00 wib sampai pukul 22.30 wib sedangkan untuk tingkat ibtidaiyah dimulai pukul 20.00 wib sampai pukul 22.00 wib.

Kondisi ini menggambarkan proses pembelajaran kitab kuning di PP. Al Falah Ploso yang sangat bagus, dengan penggunaan waktu yang full 24 jam untuk mempelajarai kitab plus diiringi pula dengan penggunaan kurikulum yang berkiblat kepada sistem Tebuireng (Mu'allimin, 2007:117). Pada masa KH Hasyim Asy'ari (lembaga yang bayak menghasilkan para ulama), dengan demikian tentunya PP Al Falah Poloso akan menghasilkan santri-santri yang mumpuni dibidang penguasaan kitab kuning.

\section{Kitab-Kitab yang digunakan}

Untuk melihat tinggi atau rendahnya kualitas pembelajaran kitab kuning, akan dilakukan perbandingan pembelajaran kitab kuning yang digunakan antara PP Al Falah (induk) dengan PP Quen Al Falah dan PP. Al Badrul Falah (pesantren cabang atau pesantren milik putra dan putri $\mathrm{KH}$ Djazuli Usman). Dimana pesantren Queen Al Falah didirikan tahun 1992 oleh KH. Munif (putra kelima) dengan system pendidikan selain diajarkan kitab kuning juga pendidikan umum sedangkan PP Al Badrul Falah didirikan tahun 2002 oleh Nyai Badriyah dengan memberikan pelajaran kitab dan pelajaran umum. PP Queen Al Falah dan PP Al Badrul Falah termasuk tipe pesantren Khalafiyah, kondisi ini berbeda dengan PP Al Falah Induk yang bertipe salafiyah murni.

Sementara itu kitab-kitab yang digunakan di PP. Al Falah Ploso sejak awal berdiri sampai sekarang baik pada jenjang klasikal dan non klasikal jumlah kitabnya tidak mengalami penurunan, bahkan pada generasi kedua (putranya KH. A. Djazuli) terjadi penambahan kitab yang diajarkan yaitu kitab yang mempelajari ilmu falak dan hisab.

Berkaitan dengan kitab-kitab yang diajarkan antara pesantren induk dan pesantren cabang sebagian mengalami perbedaan. Fan Nahwu, kitabkitab yang diajarkan mulai dari kitab Syabrowi, Jurumiyah, Imrithi sampai Alfiyah (kitab Nahwu tertinggi dikalangan pesantren). Adapun Kitab Fathul Wahab yang merupakan kitab tertinggi pada pesantren salafiyah, hanya diajarkan pada Pesantren Al Falah Induk. Sedangkan pesantren cabang hanya mengajarkan kitab Fathul Qorib dan Fathul Mu'in.

Berdasarkan jumlah pertemuan/tatap muka, pada PP Al Falah Induk materi Alfiyah diberikan selama 1 semester (6 bulan) sebanyak 96 kali pertemuan. Sedangkan di PP. Queen dan PP.Al Badr hanya 24 kali pertemuan. Dilihat dari segi jenjang pada sistem klasikal, jenjang Musyawirin yang merupakan jenjang tertinggi, hanya ada pada pesantren induk tidak ada di pesantren cabang. Artinya untuk penguasaan Ilmu Fiqih secara mendalam hanya ada di pesantren $\mathrm{Al}$ Falah Induk.

Berkaitan jumlah jam pembelajaran kitab kuning pada sekolah diniyah (Klasikal), untuk pesantren Induk tiap hari dari 07.30-jam 11.00 (270 menit), PP. Al Badr dari jam 20.00-22.00 (120 menit), dan PP Queen Al Falah dari 18.00 sampai jam 20.00 (120 menit). Sedangkan jumlah jam pembelajaran kitab kuning secara sorogan/bandongan (non Klasikal) pada pesantren induk dari jam 12.0013.30, jam 16.00-16.45, jam 18.00-19.00, jam 05.0006.00 (255 menit). PP Queen Al Falah, dari jam 16.00-1645 (45 menit), dan PP. Al Badrul Falah jam 15.00-16.30 (90 menit). Data menunjukkan bahwa jumlah jam terbanyak mempelajari kitab kuning (klasikal maupun non klasikal) terdapat di pesantren Induk $\mathrm{Al} \mathrm{Falah.}$ 
Grafik 1: Jumlah Waktu Pembelajaran Kitab Kuning (Klasikal dan Non Klasikal) Pada PP Al Falah, PP

Queen Al Falah Dan PP AL Badr Falah

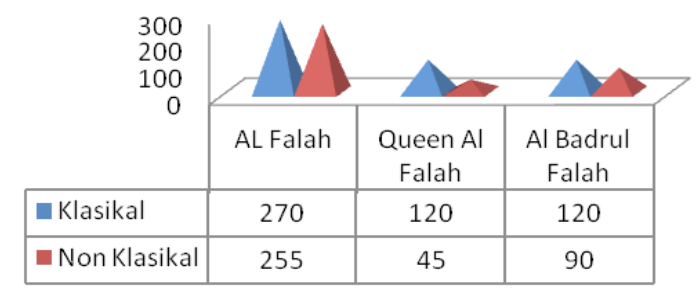

Selanjutnya proses pembelajaran kitab kuning di Al Falah Ploso, diawali dengan kegiatan syawir yaitu kegiatan belajar klompok di ruang musyawaroh yang ditentukan sesuai kelas masingmasing. Jumlah jam yang dilakukan untuk kegiatan syawir pada pesantren induk pada jam 20.00-23.00 (3 jam), sedangkan pada PP. Al Badrul Falah dari jam 18.00-19.00 (1 jam) dan PP. Queen Al Falah tidak ada kegiatan syawir.

Adapun pada sistem non klasikal kitab kitab yang digunakan antara lain Kitab Tafsir Jalalain (Tafsir), Shohih Bukhori (Hadits), Ihya' Ulumiddin (Tasawuf) Al Hikam (Tasawuf), Fathul Wahab (Fiqih). Kitab-kitab tersebut di atas termasuk kitabkitab yang kategori tinggi.

\section{Metode yang digunakan}

Pembelajaran KK di PP. Al Falah dilakukan melalui beberapa metode, diantaranya: 1) metode sorogan (proses pembelajaran diawali dengan guru membacakan kitab, kemudian santri memaknai, dilanjutkan dengan santri membaca dan menerangkan), 2) metode bandongan (dimana proses pembelajaran diawali dengan guru membacakan kitab, kemudian santri memaknai, 3) metode wethonan: proses pembelajaran diawali dengan guru membacakan kitab, kemudian santri memaknai tapi pelaksanaannya tiap satu lapan. Dengan variasi ketiga metode (sorogan, bandongan dan wethonan) ditambah oleh kedisiplinan para kyai, ustad dan santri maka menghasilkan para lulusan/alumni yang berkualitas dalam bidang agama.

\section{Sarana prasarana dalam proses pembelajaran}

Sarana dan prasana yang mendukung proses pembelajaran di pesantren Al Falah sangat lengkap diantaranya Gedung asrama yang nyaman 11 buah, ruang belajar yang representatif 42 buah, ruang pimpinan 4 buah, ruang kantor 5 buah, ruang dapur 1 buah, masjid 1 buah, keamanan siaga 24 jam, poliklinik pesantren (Politren) 1 buah, auditorium luas, perpustakaan memadai 1 buah, lapangan olahraga 1 buah dan laboratorium, serta fasilitas komputer 1 buah.

Berdasarkan hasil wawancara dengan beberapa santri, salah satu penyebab mereka tertarik masuk PP. Al Falah Ploso adalah sarana gedung yang mewah, dengan kebersihan yang terjaga. Adapun proses pembelajaran kitab kuning di kelas menggunakan sarana manual yaitu papan tulis dan buku pegangan. Perlengkapan multimedia hanya digunakan dalam saat dan acara tertentu (seperti seminar, bahtsul masail dll.) dan tidak untuk proses belajar di kelas karena menurut pengurus pesantren akan mematikan kreatifitas siswa. Disisi lain pesantren yang berciri has salafi ini melarang santrinya menggunakan HP, membaca koran, menonton TV, kondisi ini selain dapat membentengi santri-santri dari pengaruh-pengaruh negatif dari luar juga dapat meningkatkan konsentrasi santri dalam mempelajari kitab kuning.

\section{Ketercukupan Anggaran}

Sejak dari generasi kedua sampai generasi sekarang, putra dan putri KH Djazuli punya bakat dibidang wirausaha yang diwarisi dari Ibu nyai $\mathrm{Hj}$. Rodliyah Djazuli yang piawai dalam berwirausaha. Misalnya KH. Zainuddin Djazuli (anak ke 1) mempunyai usaha peternakan sapi. KH. Nurul Huda (anak ke 2) mempunyai usaha kolam ikam, KH. Fuad (anak ke 4) mempunyai peternakan ayam, sapi dan pertanian, K. Munif $\mathrm{Dj}$ (anak ke 5) mempunyai kolam ikan, Ibu Nyai HJ. Lailatul Badriyah (anak ke 6) mempunyai usaha pertanian dan perdagangan. Disini terlihat kehidupan ekonomi pimpinan pesantren yang sekaligus merupakan putra KH. Djazuli nampak sudah mapan dari sisi ekonomi. Oleh karena itu, mereka mendirikan pesantren bukan untuk mencari kehidupan dari pesantren, akan tetapi dari usaha yang dimiliki tersebut digunakan untuk menghidupi pesantren (wawancara dengan Mas Aqif, 2 Oktober 2012).

Biaya operasional pesantren semisal listrik, air, dll. Sudah tercukupi oleh I'anah dari para santri (meliputi: I'anah Pondok Rp. 550.000/tahun + I'anah Madrasah Rp. 500.000/tahun + Dana Sehat Rp. 100.000/tahun). Di sisi lain anggaran gaji/ honor guru perjam tidak ada/gratis karena para ustadz mengajar murid-muridnya dalam rangka pengabdian kepada pesantren. 


\section{Kendala Dalam Pembelajaran Kitab Kuning}

Uraian sebelumnya sudah dijelaskan beberapa faktor penunjang yang mempengaruhi kualitas pembelajaran kitab kuning. Namun dalam proses pembelajaran kitab kuning di pesantren Al Falah Ploso, ada pula beberapa faktor kendala yang dihadapi, diantaranya:

Pertama, Seiring dengan adanya era globalisasi yang ikut mempengaruhi tujuan hidup para ustadz. Peribahasa yang mengatakan "yang dipikirkan bukan apa yang harus di siapkan untuk akhirat tapi apa yang bisa kita persiapkan untuk duniawi", setidaknya mempengaruhi pola pikir para ustadz yang lambat laun akan lebih memikirkan duniawi daripada berdawah di pesantren (wawancara dengan Gus Thoif, 28 September 2012). Hal ini dapat dilihat dengan semakin berkurangnya usaha bathin (terutama puasa) dan kedisiplinan para ustadz.

Kalau dikaitkan dari 63 ustadz yang mengabdi di pondok, terdapat $25(39,7 \%)$ yang belum menikah dan menikah 38 (60,3\%). Banyaknya ustadz yang sudah menikah maka hal penting yang perlu dipertimbangkan adalah honor mengajar. Selama ini honor mengajar bisa dianggap tidak ada. Kondisi ini di mungkinkan akan mempengaruhi berkurangnya konsentrasi mengajar para ustadz, dimana mereka harus memikirkan keluarga dan juga memikirkan pekerjaannya sebagai guru.

Kedua, kualitas input santri. Pada awalnya santri yang masuk adalah santri yang punya keinginan kuat dengan segala keuletan, kedisiplinan, ketekunan. Namun, seiring dengan perubahan zaman yang ditandai dengan arus modernitas, dari 20-25\% santri yang masuk ke PP. Al Falah Ploso adalah santri yang orang tuanya sudah tidak mampu mendidik anaknya (wawancara dengan Gus Thoif, 2 Oktober 2012). Orang tua beranggapan pesantren adalah tempat memperbaiki akhlak dan tingkah laku seorang anak agar menjadi baik dan ber akhlaqul karimah. Ada pula santri yang masuk ke pesantren karena tidak lulus tes sehingga tidak dapat belajar di sekolah negeri. Kondisi input santri yang demikian, yakni tidak memiliki niat yang murni mempelajari kitab kuning di pesantren akan tetapi berangkat dari keterpaksaannya, karena dipaksa orang tua. Hal ini tentunya tidak akan mendapatkan hasil yang maksimal.

Kalau melihat grafik 2, menunjukkan bahwa selama 4 tahun terakhir santri yang lulus pada jenjang MISRIU (Ibtidaiyah, MTs dan Aliyah) mengalami penurunan dan sebaliknya makin meningkat santri yang tidak lulus.
Grafik 2: Tingkat Kelulusan Santri dari Tahun 2008 sd 2012 di PP Al Falah

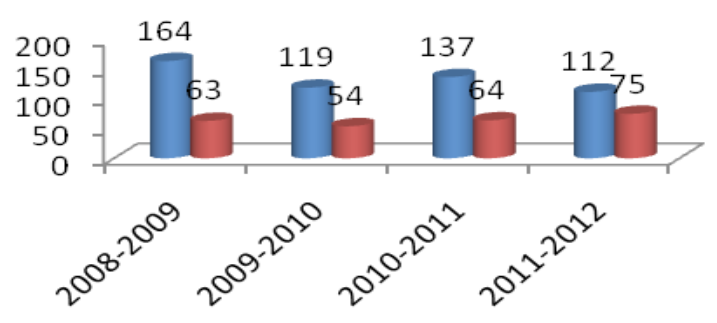

Ketiga. Kuantitas dan kualitas jenjang musyawirin. Setelah selesai menamatkan jenjang MISRIU (Ibtidaiyah, MTs, MA), santri diwajibkan mengikuti jenjang Riyadlotut Tolabah (musyawirin) yang merupakan jenjang tertinggi dan sebagai syarat syahnya seorang santri dianggap sebagai santri lulusan PP Al Falah. Data menunjukkan pada jenjang musyawrin, santri yang masuk ke jenjang ini, tahun 2010-2011 ada 407 santri, tahun 20112012 sebanyak 265 santri dan tahun 2012-2013 sebanyak 225 santri. Dari data tersebut ternyata semakin sedikit yang masuk jenjang musyawirin dan tentunya kondisi ini akan berdampak pada makin sedikitnya santri yang menjadi lulusan PP Al Falah.

Disisilain darisegikualitas terlihat juga adanya penurunan kreatifitas santri. Kalau dulu santri sudah pandai berdiskusi dengan menggunakan berbagai referensi kitab dengan suasana kompetitif yang tinggi dan waktu yang digunakan sampai larut malam jam 12. Namun sekarang terjadi sedkit penurunan, hal ini terlihat dari waktu acara di kelas musyawirin yang kurang terlihat kemampuan kompetitifnya (wawancara dengan Gus Thoif, 3 Oktober 2012).

\section{Dampak Sosial Keagamaan}

PP. Al Falah Ploso memiliki wadah yang menangani hubungan dan ikatan antara alumni dengan nama Ittihadul Mutakhorijin Al Falah Ploso. Kohesivitas antar almuni dirasakan cukup baik, dibuktikan dengan adanya pertemuan rutin antar mereka baik yang bersifat internal organisasi maupun yang bersifat keilmuan. Konstribusi para alumni kepada almamater dapat dilihat dari banyaknya bentuk bantuan sarana yang diberikan untuk pengembangan pesantren.

Di sisi lain suksesnya PP Al Falah dapat dilihat dari sejauhmana ketersebaran dan keterserapan Alumni di masyarakat, diantaranya: alumni 
yang terjun kedunia Politik (KH. Abdurrohman Khudlori), H. Jamil (Pengusaha sandal merek Carvile dan showroom mobil), KH. Hanif khudlori (pimpinan PP. API Tegal Rejo), KH. Lutfi Hakim (pengasuh PP. Buntet Cirebon). Diantara yang menjadi fuqoha' adalah KH. Arsyad Bushoir (pengasuh PP. Al Falah Trenceng Tulungagung) dan KH. Ardani Ahmad (pengasuh PP. Al Falah Blitar). Seorang mubaligh(KH. Harun Isma'il dari Blitar). Ada juga alumni yang melanjutkan ke STAIN Kediri dan PTA, serta yang memilih mengabdi di PP Al Falah.

\section{PENUTUP}

Dari uraian di atas dapat disimpulkan: Pertama, Pesantren Al Falah Ploso sudah melakukan inovasi mulai kondisi awal dengan sistem tradisional/salafiyah berupa sorogan dan wetonan, kemudian ditambahkan dengan sistem pendidikan klasikal dalam bentuk Madrasah Diniyah (Ibtidaiyah, Tsanawiyah dan Aliyah), serta Riyadlotut Tolabah dan berhasil mendapatkan predikat sistem pendidikan diniyah formal yang telah termuadalah oleh Kementerian Agama. Kedua, faktor penunjang penguasaan kitab kuning: komitmen kyai yang tinggi, kompetensi ustadz, input santri yang berkualitas, keefektifitasan kurikulum yang digunakan, tingginya kitab-kitab yang digunakan, sarana dan dana yang menunjang. Sedangkan faktor penghambat diantaranya: berkurangnya ustadz yang ahli Riyadhoh (tirakat), dan menurunnya kuantitas dan kualitas santri.

\section{UCAPAN TERIMA KASIH}

Terima kasih kepada Kepala Puslitbang Pendidikan Agama dan Keagamaan Balitbang dan Diklat Kementerian Agama dan Prof. Rusdi Muchtar, APU yang telah memberi bimbingan dan kesempatan kepada penulis untuk meneliti, serta para kyai termasuk juga seluruh pengurus pesantren Al Falah Ploso yang turut membantu memberikan data dan informasi, juga kepada Redaktur AlQalam atas termuatnya tulisan ini, semoga tulisan ini memberikan wawasan dalam pendidikan agama di Indonesia.

\section{DAFTAR PUSTAKA}

Abdul Fattah, Rohadi, dkk. 2005. Rekonstruksi Pesantren Masa Depan. Jakarta: PT Listafariska Putra.

Agil Siroj, Said. 2007. Pesantren Salafiyah di Era Globalisasi. Jakarta. Makalah di sampaikan dalam acara Pelatihan Badan Litbang dan Diklat Kementerian Agama RI.

Bruinessen, Martin Van. 1995. Kitab Kuning : Pesantren dan Tarekat. Bandung: PT Mizan

Burhanudin, Jajat. 2006. Mencetak Muslim Modern. Jakarta: Raja Grafindo Persada.

Dhofier, Zamakhsyari. 1994. Tradisi Pesantren Studi Tentang Pandangan Hidup Kyai. Jakarta: Lembaga Penelitian, Pendidikan dan Penerangan Ekonomi dan Sosial (LP3S)

Dokumen perkembangan santri di PP Al Falah Ploso tahun 2012

Dokumen profil Ustad di PP Al Falah Ploso tahun 2012

Imam Mu’allimin, Imam, dkk. 2007. KH Ahmad Djazuli Utsman Sang Blawong: Pewaris Keluruhan. Kediri: PP. Al Falah Ploso.

Mastuhu. 1993. Dinamika Sistem Pendidikan Pesantren. Jakarta: INIS.

Qomar, Mujamil. 2007. Model Model Pengembangan Pesantren Salafiyah (Perspektif Jaringan dan Perubahan Sosial). Jakarta: Balitbang dan Diklat Kementerian Agama. 